Geo-Resources

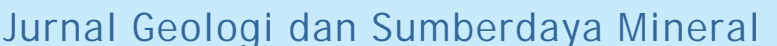

Journal of Geology and Mineral Resources

JGSHII

Center for Geological Survey, Geological Agency, Ministry of Energy and Mineral Resources Journal homepage: http://jgsm.geologi.esdm.go.i

\title{
Geologi Pegunungan Mendoke, Lengan Tenggara Pulau Sulawesi, Indonesia
}

\section{Geology of the Mendoke Mountains, Southeast Arm of Sulawesi Island, Indonesia}

\author{
Hasria $^{1}$, Arifudin Idrus ${ }^{2}$, dan I Wayan Warmada ${ }^{2}$ \\ 'Jurusan Teknik Geologi, Universitas Halu Oleo Kendari \\ ${ }^{2}$ Departemen Teknik Geologi, Universitas Gadjah Mada Yogyakarta \\ e-mail: hasriageologi@gmail.com \\ Naskah diterima : 09 April 2021, Revisi terakhir : 25 Agustus 2021 Disetujui : 26 Agustus 2021, Online : 26 Agustus 2021 \\ DOI: http://dx.doi.org/10.33332/jgsm.geologi.22.3.123-131p
}

\begin{abstract}
Abstrak-Penelitian ini dilakukan di Pegunungan Mendoke pada Lengan Tenggara Pulau Sulawesi Indonesia. Tujuan penelitian adalah untuk mengetahui geomorfologi, stratigrafi dan struktur geologi di Pegunungan Mendoke. Metode penelitian yang digunakan adalah studi pustaka, pekerjaan lapangan, analisis laboratorium berupa analisis petrografi, serta interpretasi data labororium dan hasil pengamatan lapangan. Hasil penelitian menunjukkan bahwa geomorfologi di daerah penelitian terdiri atas 3 (tiga) satuan, yaitu satuan dataran rendah, satuan perbukitan rendah berlereng sangat landai hingga agak curam dan satuan pegunungan berlereng agak curam hingga sangat curam. Adapun stratigrafi daerah penelitian dibagi menjadi 7 (tujuh) satuan, yaitu Satuan Sekis Mengkoka, Satuan Sekis Pompangeo, Satuan Intrusi Diorit, Satuan Serpentinit Harzburgit Ultramafik, Satuan Batupasir Konglomerat Langkowala, Satuan Batupasir Boepinang dan Satuan Endapan Aluvial. Daerah penelitian dikontrol oleh struktur geologi berarah tenggarabaratlaut dan timur-barat.
\end{abstract}

Katakunci: Pegunungan Mendoke, geomorfologi, stratigrafi, struktur geologi.

\begin{abstract}
This research was conducted in the Mendoke Mountains on the Southeast Arm of Sulawesi Island, Indonesia. The purpose of this study was to determine the geomorphology, stratigraphic and geological structures in the Mendoke Mountains. The research method used is literature study, fieldwork, laboratory analysis in the form of petrographic analysis, and interpretation of laboratory data and field observation.. The results showed that the geomorphology in the study area consisted of 3 (three) units, namely flat hilly unit, flat hilly steeply very flat to moderately steep and moderately steep mountainous to extremely mountainous. Stratigraphy in the research area is divided into 7 (seven) units, namely Mengkoka Schist Unit, Pompangeo Schist Unit, Diorite Intrusion Unit, Ultramafic Harzburgite Serpentinite Unit, Langkowala Conglomerate Sandstone Unit, Boepinang Sandstone Unit and Alluvial Sediment Unit. The research area is controlled by a geological structure trending southeast-northwest and east-west.
\end{abstract}

Keywords: Mendoke Mountains, geomorphology, stratigraphy, geological structure. 


\section{PENDAHULUAN}

Pulau Sulawesi terletak pada pertemuan tiga lempeng, yaitu Lempeng Benua Australia yang bergerak ke utara dan Paparan Sunda dengan kecepatan $7-8 \mathrm{~cm}$ per tahun, dan Lempeng Samudra Pasifik bergerak ke arah barat dengan kecepatan ratarata $8-10 \mathrm{~cm}$ per tahun, serta Lempeng Benua Eurasia yang relatif diam (Surono, 2013a; Gambar 1). Hal tersebut menyebabkan kondisi geologi dan geomorfologi serta dinamika tektonik kawasan ini menjadi sangat kompleks.

Stratigrafi Lengan Tenggara Pulau Sulawesi terdiri atas 3 kelompok batuan penyusun, yaitu Kompleks Batuan Malihan, Kompleks Ofiolit dan Molasa Sulawesi (Surono, 2013a; Gambar 2). Batuan metamorf di Lengan Tenggara Pulau Sulawesi umumnya disusun oleh sekis mika, sekis amfibolit, sekis klorit, rijang berjasper, sekis genesan, pualam, dan batugamping meta. Batuan metamorf di kawasan ini umumnya didominasi oleh batuan sekis mika, sekis amfibolit, sekis klorit, dan sekis genesan (Permana, 2013).

Batuan-batuan tersebut tersingkap di sepanjang utara Teluk Bone, Pegunungan Mengkoka sampai ke daerah Kolaka, di sepanjang Pegunungan Mendoke, menerus ke Pegunungan Rumbia dan Pulau Kabaena. Singkapan juga dijumpai di Pulau Buton, Pulau Wawonii dan selatan Kendari yang meliputi BoroBoro, Witokala, dan Kolono dalam jumlah kecil (Permana, 2013). Batuan metamorf Mendoke dan Rumbia disetarakan dengan Kompleks Metamorf Pompangeo yang berumur mulai Kapur sampai relatif muda, Paleosen (Parkinson, 1998). Apabila batuan metamorf ditemukan di wilayah ini yang berumur relatif muda, maka menurut kemungkinan batuan tersebut merupakan hasil pemalihan ulang selama proses imbrikasi berlangsung (Kadarusman dkk., 2004; Parkinson, 1998; Parkinson dkk., 1998). Adapun Kompleks Metamorf Mengkoka memperlihatkan kesekisan (schystosity) yang dibentuk oleh glaukofan. Batuan metamorf disusun oleh sekis grafit-mika dan mika kuarsit (Helmers dkk., 1989) dengan sisipan pualam.

Kompleks Ofiolit di Lengan Tenggara Pulau Sulawesi terdiri atas batuan ultramafik dan mafik serta sedimen pelagik. Batuan ultramafik terdiri atas harzburgit, dunit, werlit, lerzolit, websterit, serpentinit, dan piroksenit (Surono, 2013a), sedangkan batuan mafik terdiri atas gabro, basalt, dolerit, mikrogabro, dan amfibolit. Adapun batuan sedimen pelagik tersusun oleh batugamping laut dalam dan sisipan rijang merah (rijang radiolaria; Hamilton, 1979; Silver dkk.,
1983). Molasa Sulawesi terdiri atas sedimen klastika dan sedimen karbonatan. Batuan sedimen klastika terdiri atas Formasi Langkowala, Formasi Boepinang dan Pandua yang penyebarannya meluas, sedangkan batuan karbonat adalah Formasi Eemoiko menyebar setempat.

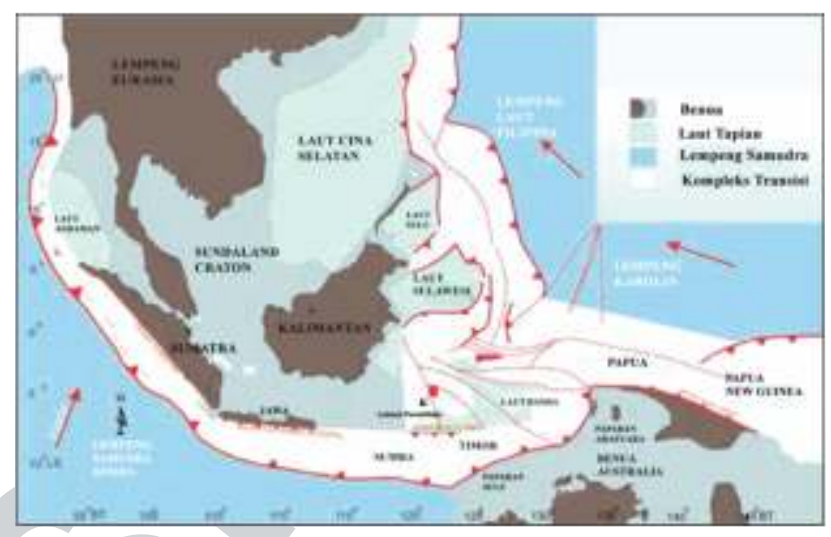

Sumber: modifikasi dari Surono (2013a)

Gambar 1. Struktur geologi dan tektonik wilayah Indonesia termasuk Pulau Sulawesi yang menunjukkan posisi tiga lempeng yang aktif saling bertabrakan.

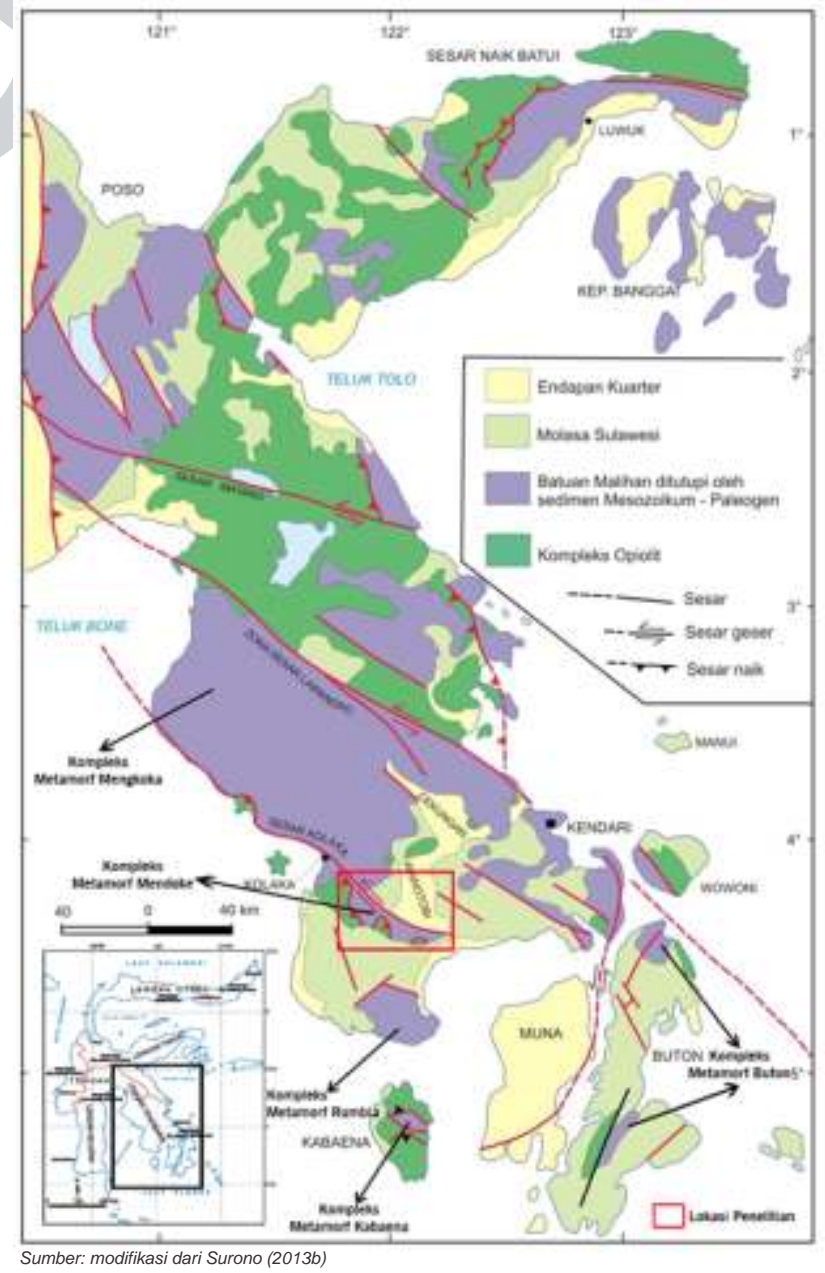

Gambar 2. Peta geologi Lengan Tenggara Pulau Sulawesi. 


\section{METODE PENELITIAN}

Metode penelitian terdiri atas 4 (empat) tahap, yaitu studi pustaka, pekerjaan lapangan, analisis laboratorium, dan interpretasi data. Studi pustaka terdiri atas pengumpulan data sekunder dan pengkajian literatur hasil penelitian terdahulu yang berhubungan dengan kondisi geologi daerah penelitian. Pekerjaan lapangan meliputi pengumpulan data primer melalui pengamatan dan pengambilan sampel representatif secara langsung di lapangan. Analisis laboratorium, yaitu analisis petrografi dilakukan dengan melakukan preparasi sampel batuan menjadi sayatan tipis (thin section) dengan ketebalan berkisar 0,03 mm yang menempel pada slide glass mikroskop. Analisis ini bertujuan untuk menentukan jenis dan kelimpahan mineral yang hadir (baik primer maupun sekunder) serta untuk mengetahui tekstur dan hubungan mineral dalam sampel batuan sehingga dapat digunakan untuk menentukan stratigrafi. Interpretasi data dilakukan secara keseluruhan sehubungan pengamatan langsung di lapangan, studi pustaka dan analisis laboratorium.

\section{HASIL DAN PEMBAHASAN}

\section{Geomorfologi}

Pembagian satuan geomorfologi daerah Pegunungan Mendoke didasarkan pada deliniasi satuan geomorfologi yang telah dilakukan oleh Surono (2013a), pengamatan langsung di lapangan dan klasifikasi geomorfologi secara morfometri menurut Van Zuidam (1983). Berdasarkan hal tersebut, maka satuan geomorfologi Pegunungan Mendoke terdiri atas 3 (tiga) satuan, yaitu satuan dataran rendah, satuan perbukitan rendah berlereng sangat landai hingga agak curam dan satuan pegunungan berlereng agak curam hingga sangat curam (Gambar 3).

\section{Satuan Dataran Rendah}

Satuan dataran rendah menempati bagian timurlaut dan sedikit pada bagian tenggara Pegunungan Mendoke dengan luas $294,91 \mathrm{~km}^{2}$ atau sekitar $28,37 \%$ total luas daerah penelitian yang berlokasi di Pegunungan Mendoke. Secara umum, satuan ini memiliki kelerengan yang datar atau sangat datar, yaitu sebesar $0-2 \%$ (Gambar 3a).

\section{Satuan Perbukitan Rendah Berlereng Sangat Landai hingga Agak Curam}

Satuan perbukitan rendah berlereng sangat landai hingga agak curam ini menempati bagian baratdaya Pegunungan Mendoke dengan luas sebesar 329,15 km² atau sekitar 31,67\% total luas daerah penelitian yang berlokasi di Pegunungan Mendoke. Secara umum, satuan ini memiliki kelerengan sangat landai hingga agak curam, yaitu sebesar 3-20\% (Gambar 3b).

\section{Satuan Pegunungan Berlereng Agak Curam hingga Sangat Curam}

Satuan ini menempati bagian tengah Pegunungan Mendoke dan memanjang ke arah baratlaut dan tenggara. Satuan ini merupakan satuan dengan luasan yang paling besar, yaitu $415,32 \mathrm{~km}^{2}$ atau sekitar $39,96 \%$ total luas daerah penelitian. Secara umum, satuan ini memiliki kelerengan agak curam hingga sangat curam atau sebesar 21-140\% (Gambar 3a dan 3b).

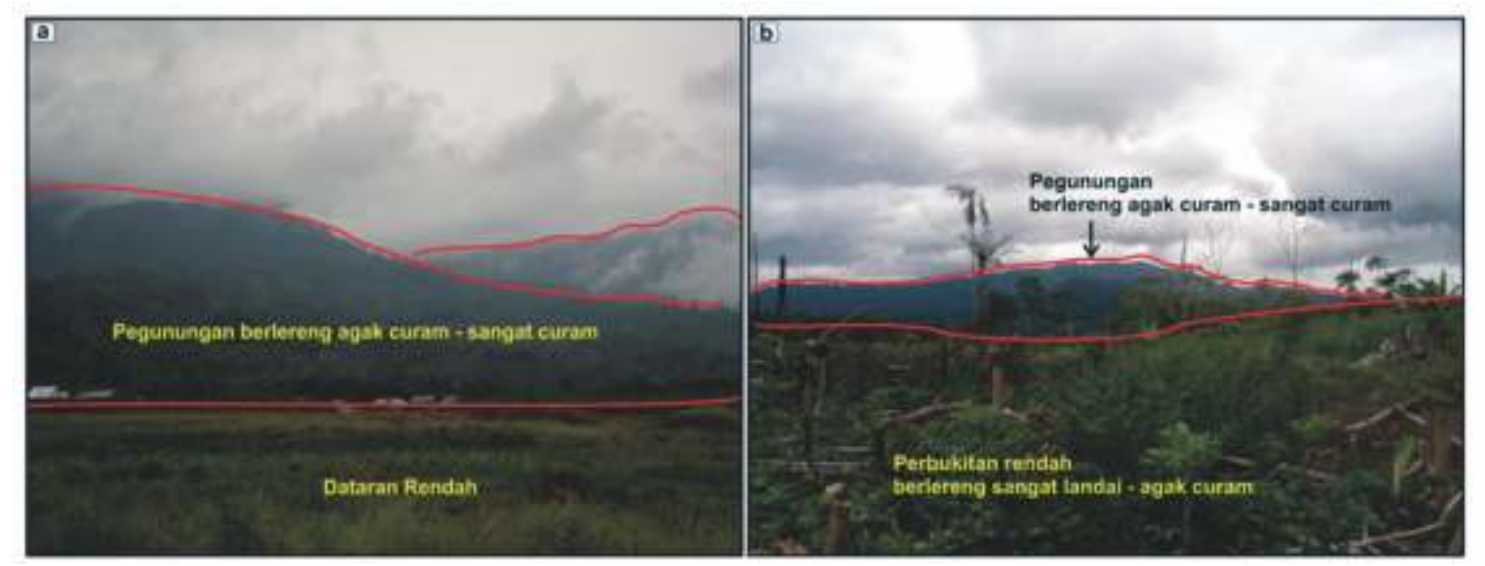

Gambar 3.Satuan geomorfologi Pegunungan Mendoke. 


\section{Stratigrafi}

Berdasarkan hasil pengamatan lapangan dan analisis laboratorium, yaitu analisis petrografi yang dikompilasi dari beberapa referensi terkait terutama peta geologi lembar Kolaka 1:250.000 (Simanjuntak dkk., 1993), maka stratigrafi daerah penelitian terdiri atas 7 (tujuh) satuan, yaitu Satuan Sekis Mengkoka, Satuan Sekis Pompangeo, Satuan Intrusi Diorit, Satuan Serpentinit Harzburgit Ultramafik, Satuan Batupasir Konglomerat Langkowala, Satuan Batupasir Boepinang dan Satuan Endapan Aluvial (Gambar 4).

\section{Satuan Sekis Mengkoka}

Satuan yang termasuk dalam kompleks batuan metamorf Mengkoka, umumnya tersingkap dalam kondisi segar, lapuk hingga mengalami alterasi hidrotermal. Satuan ini terdiri atas sekis mika dan sekis klorit dengan struktur metamorf foliasi. Hasil pengamatan lapangan di sekitar Perbukitan Tadengge, yaitu di baratlaut Perbukitan Mendoke memperlihatkan singkapan dengan struktur foliasi pada kondisi yang masih segar, umum ditemukannya kekar-kekar, ketebalan singkapan 0,5 - 1,5 m, dengan tekstur kristaloblastik, komposisi mineral kuarsa dan klorit. Hasil pengamatan secara petrografi menunjukkan mineral berwarna abu-abu, struktur foliasi-sekistosa; tekstur kristaloblastiklepidoblastik; komposisi mineral klorit, kuarsa, dan mineral opak (Gambar 5). Pentarikan umur pada satuan ini berdasarkan umur regional, yaitu berumur Paleozoikum Karbon - PerEm (Simandjuntak dkk., 1993). Satuan ini merupakan satuan batuan paling tua di daearah penelitian dan juga sebagai batuan dasar secara regional di Sulawesi Tenggara.

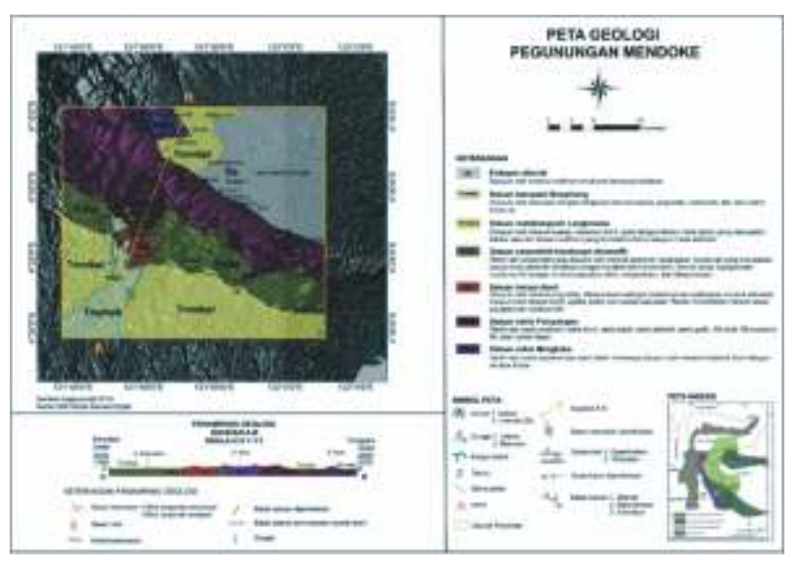

Gambar 4. Peta geologi daerah penelitian.

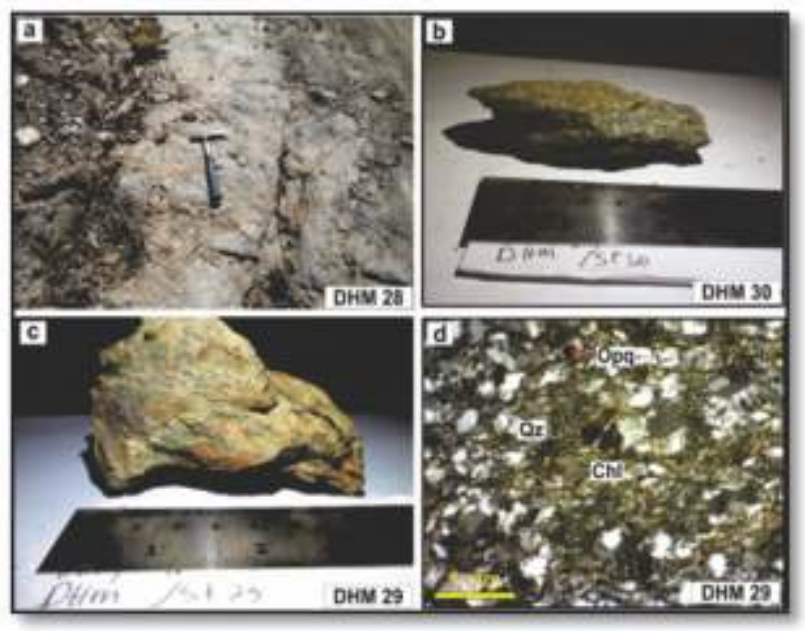

Gambar 5. Singkapan Satuan Sekis Mekongga. a) singkapan sekis dengan kekar-kekar yang menyertai bidang foliasi dari metamorf sekis; b, c) sampel batuan metamorf Mekongga yang memperlihatkan foliasi sekistosa di sekitar Perbukitan Tegengge fotomikrograf XPL satuan sekis Mekongga yang disusun oleh Qz (kuarsa), Chl (klorit), dan Opq (mineral opak).

\section{Satuan Sekis Pompangeo}

Singkapan pada satuan ini memperlihatkan batuan yang memiliki struktur metamorf foliasi yang tersingkap di sepanjang Perbukitan Mendoke, merupakan satuan batuan dengan penyebaran paling luas di daerah penelitian. Karakteristik batuan umumnya telah mengalami alterasi hidrotermal dengan kekar-kekar yang sebagian terisi mineral membentuk urat kuarsa, ketebalan singkapan sekitar 0,5-3m, tekstur kristaloblastik, komposisi mineral muskovit, klorit, grafit dan kuarsa. Hasil pengamatan petrografi sayatan tipis memperlihatkan warna abu-abu kecoklatan, struktur foliasi-sekistosa; tekstur kristaloblastiklepidoblastik; komposisi mineral umumya disusun oleh muskovit, klorit, grafit, kuarsa, mineral lempung, dan mineral opak (Gambar 6). Satuan ini berumur Mesozoikum Kapur hingga Kenozoikum Paleosen (Simandjuntak dkk., 1993). Satuan ini memiliki tekstur urat, umur dan komposisi mineral yang sama seperti di Pegunungan Rumbia (Hasria dkk., 2017), sehingga memungkinkan kehadiran mineralisasi pada satuan ini berupa emas $(\mathrm{Au})$, pirit $\left(\mathrm{FeS}_{2}\right)$, kalkopirit $\left(\mathrm{CuFeS}_{2}\right)$, stibnit $\left(\mathrm{Sb}_{2} \mathrm{~S}_{3}\right)$, hematit $\left(\mathrm{Fe}_{2} \mathrm{O}_{3}\right)$, gutit, $\left(\mathrm{FeHO}_{2}\right)$ dan kemungkinan sinabar $(\mathrm{HgS})$ yang juga hadir pada Pegunungan Rumbia.

\section{Satuan Intrusi Diorit}

Satuan intrusi ini merupakan batuan beku plutonik yang menerobos Batuan Metamorf Pompangeo (Gambar 7). Kenampakan di lapangan umumnya ditemukan dalam keadaan segar hingga mengalami alterasi hidrotermal. Singkapan ini terekam di Perbukitan Watamohai, yaitu di bagian selatan Lembah Osuwa. Pada singkapan 
ditemukan kekar-kekar yang berkembang baik, singkapan batuan berwarna abu-abu kecoklatan kehijauan, struktur masif secara umum, tekstur holokristalin, fanerik kasar, komposisi mineral umumnya plagioklas dan piroksen yang merupakan mineral primer dengan mineral klorit yang merupakan mineral sekunder. Berdasarkan pengamatan petrografi sayatan batuan memperlihatkan warna abuabu dan abu-abu hingga kuning kecoklatan; struktur masif dan sebagian telah teralterasi; tekstur holokristalin, fanerik kasar, eubhedral-anhedral, equigranular hipidiomorfik; kompisisi mineral plagioklas, klinopiroksen sebagai mineral primer sedangkan kalsit, epidot, kuarsa dan mineral opak sebagai mineral sekunder. Umur satuan ini berdasarkan umur regional, yaitu berumur Mesozoikum Kapur (Simandjuntak dkk., 1993). Satuan ini merupakan batuan terobosan yang merupakan bagian dari satuan ultramafik Sulawesi Tenggara (Surono, 2013) dan menerobos satuan batuan sekis Pompangeo.

\section{Satuan Ultramafik}

Satuan ini merupakan bagian Kompleks Ofiolit yang didominasi oleh batuan ultramafik, mafik serta sedimen pelagik (Gambar 7). Batuan ultramafik di daerah penelitian terdiri atas batuan metamorf serpentinit dan batuan beku plutonik ultrabasa harzburgit (peridotit). Kondisi singkapan umumnya dalam keadaan segar, lapuk hingga telah mengalami alterasi hidrotermal dengan kekar-kekar berkembang baik, ketebalan singkapan 0,5-1 m, struktur batuan secara keseluruhan bersifat masif. Singkapan batuan tersebar di sepanjang Perbukitan Watamohai. Hasil pengamatan lapangan memperlihatkan pada peridotit batuan berwarna abu-abu kecoklatan, struktur masif, holokristalin, fanerik kasar, komposisi mineral disusun oleh olivin dan piroksen, sedangkan serpetinit batuan berwarna abu-abu hingga coklat kekuningan, struktur non-foliasi, tekstur kristalobalstik, komposisi mineral serpentin. Berdasarkan pengamatan petrografi pada peridotit berwarna abu-abu, struktur masif; tekstur holokristalin, fanerik kasar (1-7 mm), euhedral, equigranular panidiomorfik; komposisi mineral umumnya disusun oleh olivin, ortopiroksen, sedikit klinopiroksen, dan mineral opak; nama batuan secara petrografi yaitu harzburgit. Pada serpentinit memperlihatkan warna abu-abu, struktur non-foliasinematoblas; tekstur kristaloblastik-nematoblastik; komposisi mineral disusun oleh serpentin, olivin, dan sedikit klorit, opak (Gambar 8). Umur satuan ini berdasarkan umur regional, yaitu berumur Mesozoikum Kapur (Simandjuntak dkk., 1993). Satuan ini merupakan bagian dari Kompleks
Ultramafik Sulawesi Tenggara. Berdasarkan pengamatan lapangan dan peta geologi, hubungan stratigrafi satuan ini terhadap satuan batuan di atasnya adalah tidak selaras.
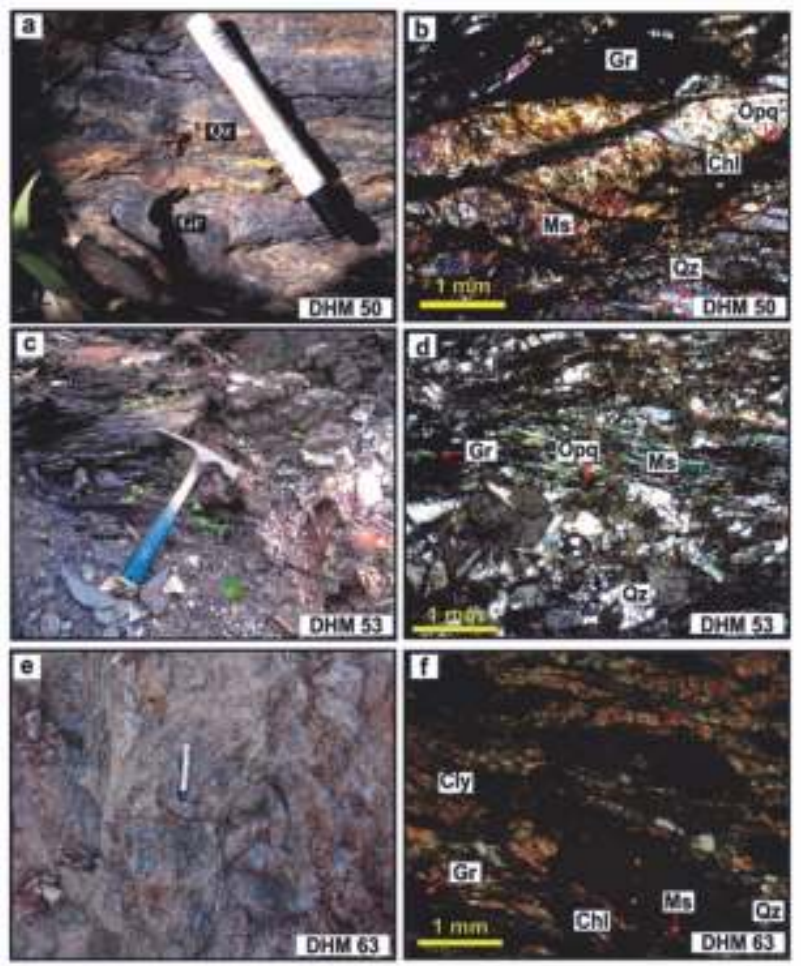

Gambar 6. Kenampakan singkapan Satuan Sekis Pompangeo. a) sekis grafit dengan sisipan urat kuarsa; c,d) sekis mika dan sekis klorit dengan sisipan urat kuarsa dengan struktur foliasi pada kondisi batuan rapuh; $b, e, f)$ fotomikrografi pada XPL dari batuan sekis grafit, sekis mika dan sekis klorit sekis klorit. Ms (muskovit), Chl (klorit), Qz (kuarsa), Gr (grafit), Cly (mineral lempung), Opq (mineral opak).
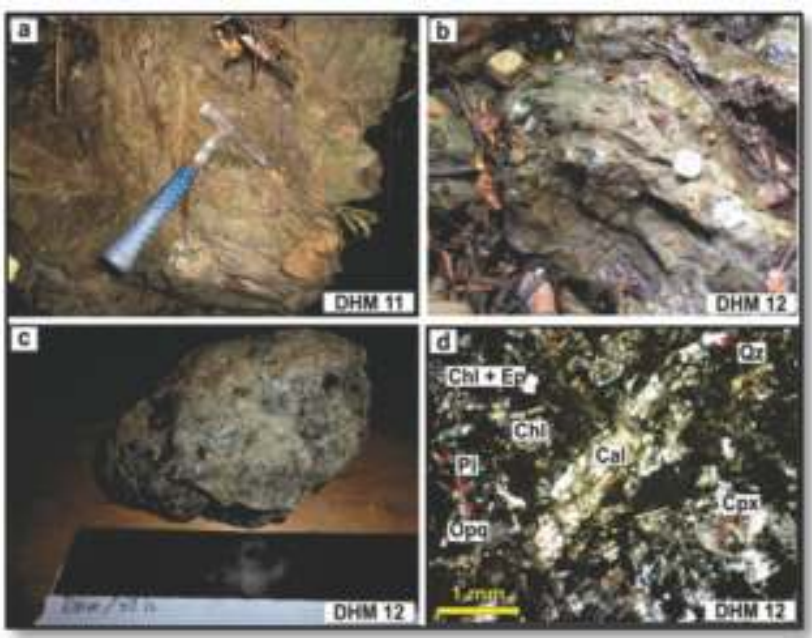

Gambar 7. a, b). Kondisi singkapan Satuan Intrusi Diorit dengan kekar-kekar teramati dengan baik, c) sampel batuan diorit yang memperlihatkan warna abu-abu kehijauan, d) fotomikrografi pada XPL diorit dengan komposisi mineral Pl (plagioklas), Cpx (klinopiroksen), Qz (kuarsa), Ep (epidot), Cal (kalsit), Opq (mineral opak). 


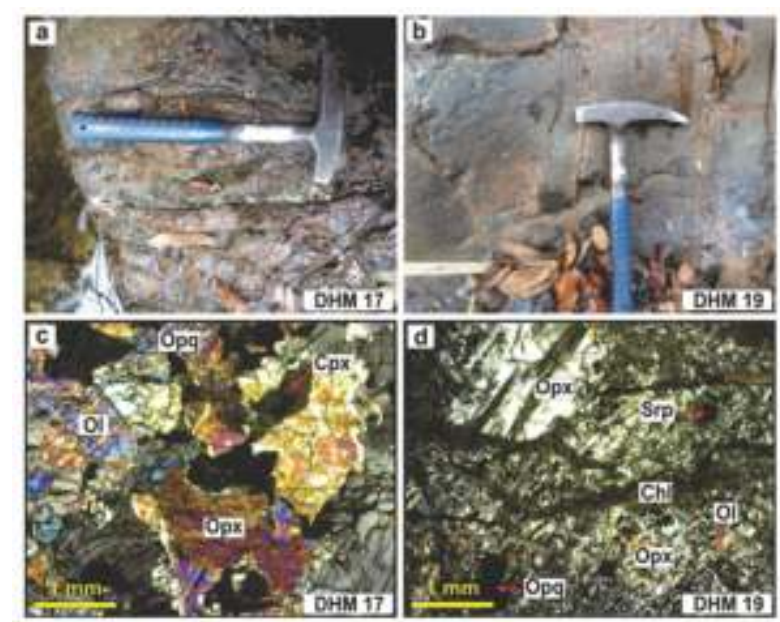

Gambar 8. Kenampakan singkapan a) peridotit-harzburgit dengan kekar-kekar yang terekam dengan baik, b) serpentinit juga ditemukan kekar-kekar yang memotong dari singkapan serpentinit (kode sampel DHM 19), c) fotomikrografi pada XPL harzburgit, d) fotomikrografi pada XPL serpentinit. Ol (olivin), Srp (serpentin), Opx (ortopiroksen), Cpx (klinopiroksen), Chl (klorit), dan Opq (mineral opak).

\section{Satuan Batupasir Konglomerat Langkowala}

Penyebaran satuan ini terletak pada bagian timur daerah Pegunungan Mendoke dengan litologi tersusun oleh perselingan antara batupasir dan konglomerat yang merupakan perulangan endapan. Dari pengamatan terhadap profil singkapan menunjukkan bahwa pada bagian atas tanah penutup (top soil) mempunyai ketebalan bervariasi dari 10-35 $\mathrm{cm}$ dan berwarna abu-abu cerah hingga abu-abu gelap. Kemudian disusul dengan lapisan pasir sedang hingga kasar yang umumnya berwarna coklat kehitaman dan abu-abu kecoklatan, ukuran butir 1/8 2,0 mm, bentuk butir membundar (rounded) hingga membundar tanggung (subrounded), ketebalan bervariasi antara 0,21-2,0 meter. Satuan ini merupakan bagian Molasa Sulawesi Formasi Langkowala Anggota Batupasir Konglomerat (Gambar 9). Pada lapisan bawahnya terdapat endapan pasir konglomeratan dengan ketebalan bervariasi antara $0,30-1,18 \mathrm{~m}$, warna bervariasi antara lain coklat kekuningan, coklat kehitaman dan abu-abu kecoklatan, ukuran butir antara 1,0-64 mm. Fragmen terdiri atas kuarsa, rijang, sekis, genes, bentuk butir membundar tanggung, ukuran butir $2-64 \mathrm{~mm}$, matriks berukuran 1/16-2 mm, bentuk butir membundar tanggung-membundar dan tersemen lempung. Batuan tersebar di Desa Mata Osu. Pentarikan umur pada satuan ini mengacu pada umur regional, yaitu berumur Miosen (Simandjuntak dkk., 1993).

\section{Satuan Batupasir Boepinang}

Satuan ini merupakan bagian Molasa Sulawesi yang secara umum disusun oleh batupasir dengan kondisi segar hingga lapuk. Singkapan memperlihatkan struktur perlapisan, dengan warna abu-abu kecoklatan dengan ukuran butir pasir kasar, terpilah baik, membundar menyudut tanggung, kemas tertutup, komposisi mineral kuarsa, klorit, dan matrik lempung. Satuan ini tersingkap di sekitar Sungai Awiu yaitu berada di bagian selatan Lembah Osuwa (Gambar 10). Hasil pengamatan sampel batuan secara petrografi memperlihatkan warna abu-abu kecoklatan, struktur masif, ukuran butir sedang-kasar (0,25-1 mm), membundar-menyudut tanggung, terpilah baik, kemas tertutup dengan point hingga long contact; komposisi mineral disusun oleh kuarsa, plagioklas, fragmen litik, horblende, dan klorit, sebagai fragmen, matrik berupa lempung, semen silika, dan kehadiran mineral opak. Umur satuan ini mengacu pada umur regional, yaitu berumur Miosen Akhir-Pliosen (Simandjuntak dkk., 1993).

\section{Satuan Endapan Aluvial}

Satuan endapan aluvial ini memiliki karakteristik berupa material sedimen dengan ukuran lempung hingga kerakal ( $<0,004$ - $64 \mathrm{~mm}$; Gambar 11), terpilah buruk, dan bersifat lepas. Material tersebut umumnya terbawa oleh sistem fluvial ataupun arus sungai, seperti di sekitar Sungai Lambandia. Penyebaran satuan ini juga terekam di daerah Susua dan Inotundotalambe, yaitu di bagian utara hingga timurlaut Perbukitan Mendoke (Gambar 11).Berdasarkan umur regional serta satuan ini merupakan hasil proses erosi dan sedimentasi yang terjadi secara terus menerus dan berlangsung hingga sekarang, maka dapat disimpulkan satuan ini berumur Holosen - Resen (Simandjuntak dkk., 1993). Hubungan stratigrafi satuan ini tidak selaras terhadap satuan batuan di bawahnya.

\section{Struktur Geologi}

Beberapa pendekatan dan tahapan di dalam menentukan dan mendeliniasi struktur geologi untuk menentukan sesar dan kekar di Pegunungan Mendoke dan sekitarnya, antara lain:

1.Penarikan kelurusan dan struktur geologi berdasarkan peta model elevasi digital sesuai dengan skala peta yang digunakan, yaitu 1:50.000.

2.Identifikasi struktur geologi di lapangan.

3.Integrasi data struktur dengan kondisi geologi di daerah penelitian. 


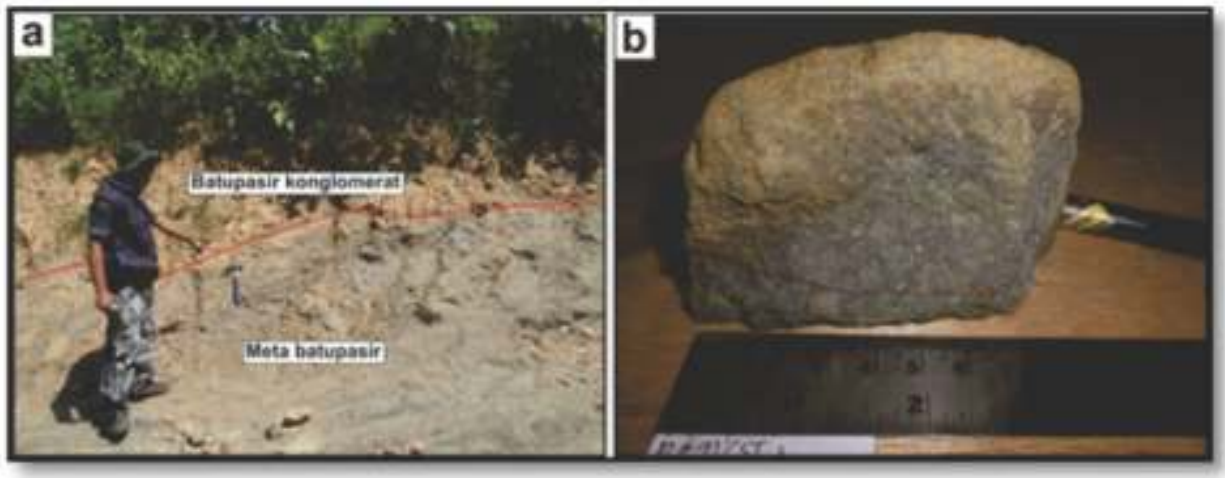

Gambar 9. Satuan Batupasir Konglomerat Langkowala. a) Singkapan yang menunjukkanbatupasir konglomerat, b) Sampel batupasir konglomerat.
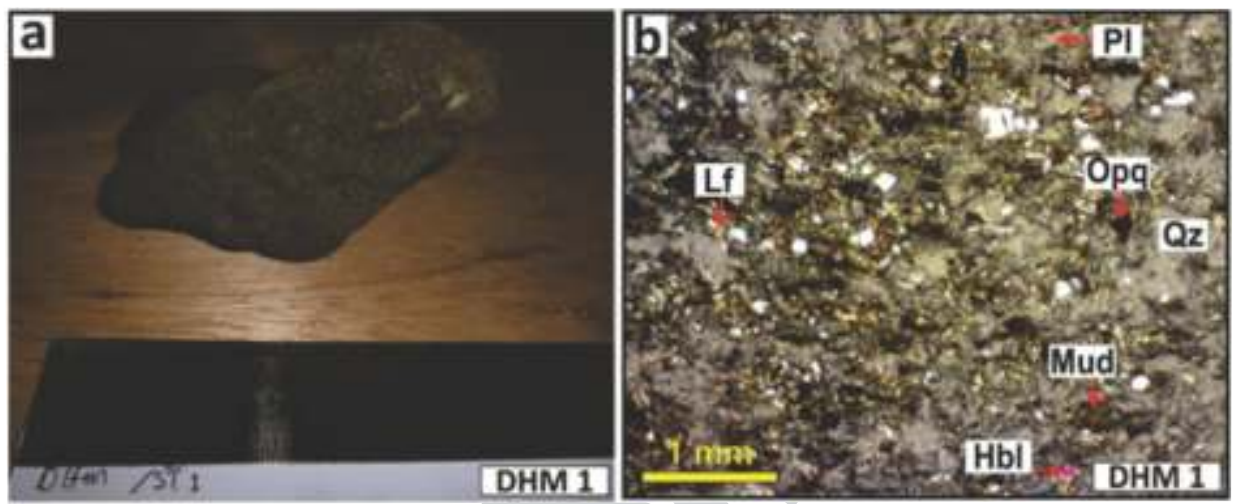

Gambar 10. Kenampakan singkapan Batupasir Boepinang. a) sampel batuan setangan batupasir yang memperlihatkan lapisan kuarsa, b) fotomikrografi pada XPL batupasir dengan komposisi mineral Qz (kuarsa), Lf (fragmen batuan), Pl (plagioklas), Hbl (hornblende), Chl (klorit), Mud (marik lempung atau lumpur), dan Opq (mineral opak).

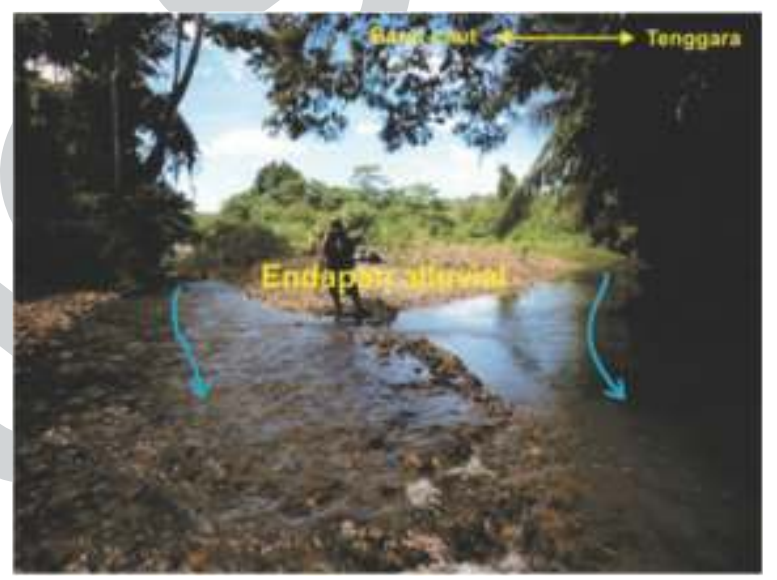

Gambar 11. Satuan Endapan Aluvial di Pegunungan Mendoke.

Pola kelurusan Pegunungan Mendoke diperoleh dari hasil penarikan kelurusan punggungan, lembah dan interpretasi keberadaan struktur geologi seperti sesar menggunakan peta model elevasi digital sesuai dengan skala penelitian, yaitu 1:50.000 (Gambar 12). $\mathrm{Hal}$ ini diharapkan dengan penarikan kelurusan ini dapat membantu menginterpretasi keberadaan sesar, termasuk pergerakan dan jenis sesar yang mengontrol kondisi geologi daerah penelitian. Berdasarkan hasil analisis yang dilakukan, tampak bahwa kelurusan berarah tenggara-baratlaut merupakan arah paling dominan, kemudian arah timurlaut-baratdaya, dan hanya beberapa yang mendekati arah utara-selatan dan barattimur yang tercermin pada diagram mawar pada peta kelurusan. 


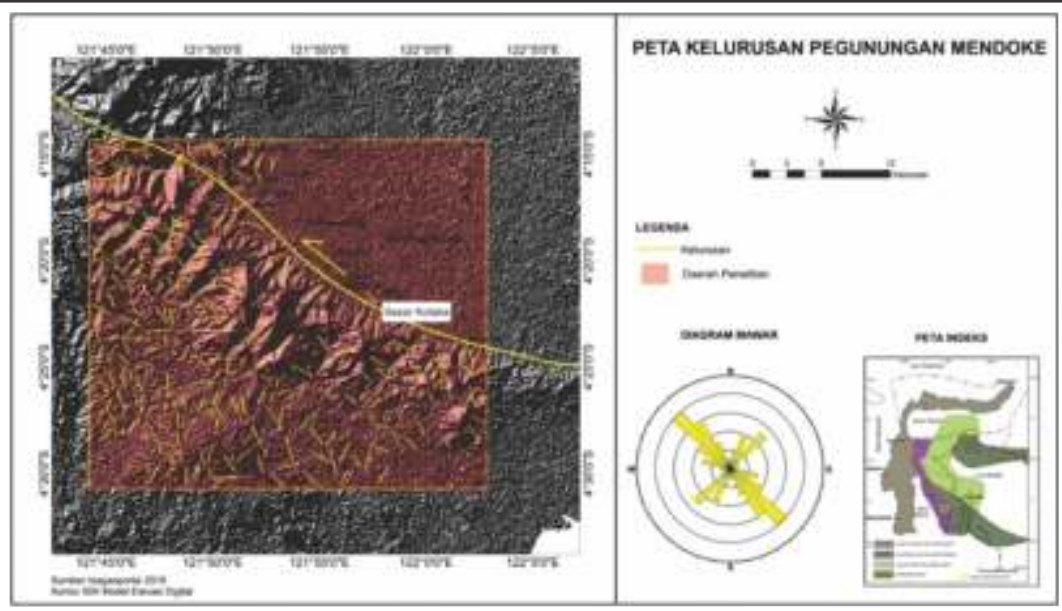

Gambar 12. Peta kelurusan yang dilakukan penarikan berdasarkan skala peta yang digunakan di Pegunungan Mendoke dan sekitarnya.

Struktur sesar yang terbentuk di Pegunungan Mendoke dan sekitarnya diinterpretasi sebagai hasil proses peristiwa geologi yang terjadi pada fase pembentukan suatu formasi batuan. Pada sesar naik diinterpretasikan terjadi akibat adanya proses pengangkatan pada batuan dasar yang diiringi dengan tektonik kompresi, sehingga menyebabkan blok-blok ataupun bagian dari formasi batuan dasar ini mengalami pengangkatan seperti sesar-sesar naik pada Satuan Sekis Mengkoka, Satuan Serpentinit Harzburgit Ultramafik dan Satuan Sekis Pompangeo.

Keberdaaan sesar turun umumnya ditemukan pada Satuan Sekis Mengkoka yang dibuktikan dengan topografi longsoran yang membentuk morfologi lembah, sedangkan sesar turun lainnya teridentifikasi pada Satuan Sekis Pompangeo. Hal ini diinterpretasi sebagai hasil tektonik regangan sehingga memunculkan sebagian blok-blok pada Sekis Pompangeo mengalami penurunan. Keberadaan sesar mendatar umumnya memotong sesar naik. Sesar mendatar ini tersebar secara merata di setiap satuan batuan penyusun stratigrafi daerah penelitian. Sesar ini diinterpretasikan sebagai fase akhir proses pembentukan struktur geologi yang mempengaruhi kondisi geologi di Pegunungan Mendoke dan sekitarnya.

\section{KESIMPULAN}

Geomorfologi di daerah penelitian terdiri atas 3 (tiga) satuan, yaitu satuan dataran rendah, satuan perbukitan rendah berlereng sangat landai hingga agak curam dan satuan pegunungan berlereng agak curam hingga sangat curam. Stratigrafi daerah penelitian dibagi menjadi 7 (tujuh) satuan, yaitu Satuan Sekis Mengkoka, Satuan Sekis Pompangeo, Satuan Intrusi Diorit, Satuan Serpentinit Harzburgit Ultramafik, Satuan Batupasir Konglomerat Langkowala, Satuan Batupasir Boepinang dan Satuan Endapan Aluvial. Daerah penelitian dikontrol oleh struktur geologi yang berarah tenggarabaratlaut dan timur-barat.

\section{UCAPAN TERIMAKASIH}

Terimakasih kami sampaikan kepada Bupati Konawe Selatan, Kolaka Timur, Kolaka dan Bupati Bombana karena telah memberikan izin penelitian di Pegunungan Mendoke Sulawesi Tenggara. Terimakasih juga kami sampaikan kepada Laboratorium Pusat Teknik Geologi Universitas Gadjah Mada (UGM) Yogyakarta yang telah memberikan izin dalam menggunakan fasilitas untuk menganalisis sampel kami. Terimaksih kepada mahasiswa Teknik Geologi Universitas Halu Oleo yang telah ikut membantu pengambilan sampel di lapangan.

\section{ACUAN}

Hamilton, W.B., 1979. Tectonics of the Indonesian Region. U.S. Govt. Print. Off.,. doi: 10.3133/pp1078

Hasria, Idrus, A., Warmada, I.W., 2017. The Metamorphic Rocks-Hosted Gold Mineralization At Rumbia Mountains Prospect Area In The Southeastern Arm Of Sulawesi Island, Indonesia. J. Geosci. Eng. Environ. Technol. 2: 217-223. doi: 10.25299/jgeet.2019.4.1

Kadarusman, A., Miyashita, S., Maruyama, S., Parkinson, C.D., Ishikawa, A., 2004. Petrology, Geochemistry and Paleogeographic Reconstruction of the East Sulawesi Ophiolite, Indonesia. Tectonophysics. doi: 10.1016/j.tecto.2004.04.008 
Parkinson, C., 1998. An Outline of the Petrology, Structure and Age of the Pompangeo Schist Complex of Central Sulawesi, Indonesia. Isl. Arc. doi: 10.1046/j.1440-1738.1998.00171.x

Parkinson, C.D., Miyazaki, K., Wakita, K., Barber, A.J., Carswell, D.A., 1998. An Overview and Tectonic Synthesis of the Pre-Tertiary Very-high-pressure Metamorphic and Associated Rocks of Java, Sulawesi and Kalimantan, Indonesia. Isl. Arc, 7: 184-200. doi: 10.1046/j.1440-1738.1998.00184.x

Permana, H., 2013. Kompleks Batuan Malihan, in: Surono, Udi Hartono (Eds.). Geologi Sulawesi. Badan Geologi Bandung.

Silver, E.A., McCaffrey, R., Joyodiwiryo, Y., Stevens, S., 1983. Ophiolite Emplacement by Collision Between the Sula Platform and the Sulawesi Island Arc, Indonesia. J. Geophys. Res., 88: 9419-9435. doi: 10.1029/JB088iB11p09419

Simandjuntak, T.., Surono, Sukido, 1993. Peta Geologi Lembar Kolaka, Sulawesi, Skala 1:250.000. Pusat Penelitian dan Pengembangan Geologi, Bandung.

Surono, 2013a. Geologi Lengan Tenggara Sulawesi. Badan Geologi, Kementerian Energi dan Sumber Daya Mineral Jl. Diponegoro No. 57 Bandung 40122 Telp. 022-7215297, Fax. 022-7218154.

Surono, 2013b. Kepingan Benua, in: Surono, Hartono, U. (Eds.). Geologi Sulawesi. LIPI Press, Jakarta.

Van Zuidam, R. A., 1983. Guide To Geomorphologic Aerial Photographic Interpretation and Mapping, Section Of Geology And Geomorphologi. ITC Enschede The Netherlands. 